\title{
FAULTY MACHINES
}

A logical position.

\section{BY GRETCHEN TESSMER}

$\mathrm{D}$ aniel was no Optimus Prime - or whatever the kids expected when we finally got around to making battle robots. And I was no 'Dr Lucy Frankenstein', although that didn't stop the name from being tossed around in the newspapers like I was born with it.

I didn't mind so much. We all need a touchstone. Something familiar to link the present with the past, to centre us when the world falls to pieces.

Anyway, the war had been ongoing for some time. Everyone was tired. That sort of blind rage, the kind that denies the similarities between two bickering factions, and ignores all that grey space in between ... well, it's hard to maintain even if you're programmed for it. Faulty logic makes for faulty machines.

In the end, we took a page from antiquity and decided that our most recent differences should be settled the old-fashioned way. Single combat. To the victor, the spoils. They made their champion and I made ours. Daniel was everything a white knight should be, standing 100 feet tall, with titanium alloy armour and a vast array of weapons in his arsenal, ranging from high-tech to ancient relics. As a tribute to Achilles, I embedded the source of his force-field in a brass-plated shield worn on his back.

When I showed them the finished product, the boys and girls at the defence department were struck speechless. In a good way. But soon, they wanted more. They wanted Daniel to have feelings. They insisted on it.

"If Daniel doesn't take pleasure in his win, how will we?" they said, as if it was all so certain.

I explained the risks. I explained the way these things tend to go. But they didn't care.

"It's imperative that you understand this," they told me, reminding me, as they so often did, that the outcome of this contest meant everything. I so easily forgot the stakes, my mind distracted by the fact that Roger, Veronica and my father were dead and win, lose or draw - they weren't coming back. My family wasn't coming back.
That sort of distraction is hard to shake.

But the defence teams were adamant. "The other side must lose. No matter what happens, Lucy, they must lose."

As soon as the horn blew, signalling the beginning of the match, Daniel drew his sword. He swung it gracefully, high and strong, before bringing it down hard, sinking the blade deep into the sand of the arena. And then he knelt before his challenger, saying: "Nothing good can be decided today."

The challenger didn't laugh. He wasn't made that way. But his people did, sending up a holler of sure victory from their side of the arena. In response, hisses and shouts erupted from our side. The same old rage quickly boiled over and we were a breath away from cycling back to the same old violence that this whole contest was supposed to avoid.

I cried. Not because we might lose. Not because our plan had failed. And not because I knew what Daniel would do next. Feelings or not, he was programmed for one purpose. And that purpose was that the other side must lose.

I didn't love Daniel (honestly, I didn't love anyone anymore), but he loved me. I was his mother and he looked to me for guidance and approval. The Frankenstein jokes weren't original but they were accurate enough.

The day before the fight, as I soldered his left wrist-guard shut, he asked me: "Lucy, why is it so important that we win and they lose?"

"Faulty logic," I muttered, more to myself than to him. I considered keeping my mouth shut. Roger always begged me to keep quiet. You can scream at a tidal wave, Lucy. But it'll still swallow you whole. And my father: Not all battles are fought where we can see them.

Daniel waited, hoping for more. My gentle giant never pushed, just waited. So I added, voice breaking only slightly on the same words that Veronica, my clever little girl, once said to me, after I asked her why she was hiding beneath the bed during a thunderstorm when she knew the storm was miles away. "Because it's hard to be the right kind of brave." $\rightarrow$ NATURE.COM Follow Futures: * @ NatureFutures

$f$ go.nature.com/mtoodm
Their battle robot was bigger. Isn't that always the way it goes?
No, I cried because I know how it feels to disappoint the ones you love. And worse, fail to save them. Not my father from old age or Roger from the whims of martial law or Veronica from the bitter pill of collateral damage.

As I watched Daniel hesitate, I knew he felt it too. Just before the challenger's killing blow, Daniel looked for me in the crowd. He shouldn't have but faulty logic makes faulty machines. He was looking for my permission. I shrugged through my tears, unsure as always.

He made the decision, tearing off his left wrist-guard to reveal the kill switch beneath. It would destroy Daniel, together with everyone and everything within a 50 -mile radius. The boys and girls from defence cried out their warnings and "for God's sake, stop!" too late. But I'm not sure why they objected.

The other side certainly lost. And oh, wasn't that what they all wanted? -

Gretchen Tessmer is an attorney/writer based in the US-Canadian borderlands of Northern New York. Follow her on Twitter: @missginandtonic. 